\title{
District/Municipal Government Authority in Regulating the Conversion of Sustainable Food Agriculture Land
}

\author{
Putu ayu rianita, I Made Suwitra \\ \{ayu.rianita27@gmail.com\} \\ Universitas Warmadewa, Denpasar-Bali, Indonesia
}

\begin{abstract}
This study examines the basis of district/municipal government authority in regulating the function conversion of sustainable food agriculture and investigates juridical consequences of the application of the disctrict/municipal Government on Sustainable Food Agricultural Land Protection without complying with the Provincial Regulation. We used normative legal study design with statutory and conceptual approaches to achieve these objectives. We found that the district/city government regulated conversion of sustainable agriculture land of food that is in Number 41 of Article 12 in 2009. The arising juridical consequence is it contradicts with point (2) of the Act as well as contradicting legal hierarchy of Indonesian law, and consequently the regulation is inapplicable.
\end{abstract}

Keywords: Land conversion, Sustainable Food Agriculture, Authority, Regional Regulation

\section{Introduction}

Indonesia is a rich country in natural resources $[1,2]$. One of the most productive natural resources is land. Constitutionally land in Indonesia is controlled by the state. It is based on stipulation in Indonesian Act of 1945 constitution [3]. Furthermore, juridical provisions governing the existence of land are contained in Indonesian Act of agrarian, called UUPA. Based on the Act, the state as an organization for all Indonesian people is granted an entitlement of controling all earth, water, and other natural resources in Indonesian jurisdiction. Unfortunately, the fundamental problem that has been a great challenge for the people and government of Indonesia today is the increasingly widespread of conversion of the land function for development interests, such as settlement, tourism development, shop establishment, and industry development $[4,56,7]$. In this context, land conversion is an activity to change the land use from an activity to another $[8,9]$. This condition has become a form of great challenge for the community and government that must be dealt with seriously with the power of legal provisions.

Even though Indonesia has had the Sustainable Food Agriculture Land Protection Act (hereinafter referred to as UUPLP2B), land conversion is still unresolvable. The growing population and needs, especially in urban areas require more land to remain in supply. As a result, land inventories in urban areas are increasingly limited and trigger an expensive price. To meet the increasing demand for land, urban development is expanded to the periphery where the main and fertile agricultural land was located[10]. Since the law was issued in 2009, its implementation has not worked effectively. Although a number of regional regulations have been compiled, however, land conversion continues to happen; it is slowly started from 
productive irrigated rice fields. Thus, this situation increasingly triggers the high challenges that must be resolved through legal channels by the government.

Related to $U U P L P 2 B$, the establishment of sustainable agricultural land preservation in essence has been covered in Regional Regulation No. 16 of 2009 concerning the Regional Spatial Planning of Bali Province. However, it is not enough to control the conversion of land function. As a precautionary measure, the regional government issued a regulation for the processing of sustainable agricultural land to control the conversion of the land. In line with this idea, the Jembrana district government, a part of a very influential district government in the Bali province, has proactively taken steps to control the conversion of sustainable food agriculture land. Hence, the regional regulation of Jembrana district Number 5 of 2015 concerning the Protection of Sustainable Food Agriculture Land was issued.

Judging from the conditions described earlier, there are unclear norms that need to be clarified, especially regarding the protection of community agricultural land that must be sustainable. Therefore, this study reveals the real situation about the condition of the rights and authority of urban regional governments in regulating law in the land sector, especially with regard to the transition of functions. In particular, this paper discusses the legal bases governing the urban regional government authority in controlling sustainable land conversion. It analyzes the consequences that occur because of the enactment of regional regulations in an effort to protect the land sustainably if not based on provincial regulations.

To realize the examining efforts of the phenomena examined in this paper; we made use the theory of authority with the Stufenbau concept and the theory of legal certainty. Authority theory is often equated with the Dutch term bevoegdheid, which means authority or power. It is an important portion of the law of governance, since it determines whether a new government may carry out its duties or not. Stufenbau's theory is a hierarchical theory concerning the legal system introduced by Hans Kelsen which states that legal systems are a system of steps with tiered rules; the relationship between norms that govern the actions ofcertain norms and other norms can be called super relations and sub-ordination spatial. Based on this hierarchy theory, legal norms are tiered and layered in an arrangement. In other words, a lower norm applies, sourced and based on a higher norm, and so on. Meanwhile, reviewing from the point of view of Certainty Utrecht theory, the meaning contained in legal certainty consists of two: first, which regulates each individual to become familiar with the recommendations and prohibitions for him or her are general rules. Second, they are a kind of guarantees for individuals provided by the government that enable them master what the state might execute and might not execute toward each individual. In addition to being in legal articles, the certainty of the law is in consistent decisions between judges for similar cases that have been resolved.

This study is carried out using normative legal method. This happended because of having identified that there is obscurity in the norms in Act number 41 of 2009 regarding Sustainable Protection of Land of Food Agriculture. Normative legal research is conducted to find solutions to the settlement of legal problems found in this study, namely prescription regarding solutions to the issues raised, rather than accepting or rejecting proposed decisions [11]. In addition, we used several approaches to support the activities in this study. The approaches we used are statute approach, analytical approach, and conceptual approach. The three approaches were used as a guide for the analysis of activities related to the problem of sustainable conversion of agricultural food land and the juridical consequences of the enactment of district/manucipal regulations on the Protection of Sustainable Food Agriculture without being based on provincial regulations.

There are various legal materials used in this paper. They include: 
1) Primary legal materials: binding legal materials. These include Indonesian Constitution of 1945; Number 5 of the Act on UUPA of Year 1960; and Number 41 of the agriculture land protection of 2009. Additioally, Number 12 of Legislation Formation of 2011, Number 23 of Regional Government of 2014, Government Regulation Number 1 Year 2011 concerning Determination and Function Conversion of Sustainable Food Agriculture Land, Regional Regulation of Bali Province Number 16 of 2009 concerning Governance Plan Bali Province Regional Space, Jembrana District Regional Regulation Number 5 Year 2015 concerning Sustainable Food Farmland Protection.

2) Secondary legal materials: Thhese include the work of experts in the field of law, and in the form of textbooks, journals, and magazines.

3) Tertiary legal materials: these are materials add to details of primary and secondary legal materials [12], i.e. Language Dictionary and Black Law Dictionary.

Primary, secondary and tertiary legal materials were collected through documentation and note taking techniques. Documentation is carried out by examining official documents about the regulation of conversion of sustainable food agriculture land. Note-taking is carried out by systematically recording the information obtained related to the conversion of food land. After the data were collected, everything was analyzed with systematic and grammatical interpretation techniques. Interpretation is a technique in making arguments through legal reasoning with the aim of finding concrete laws in certain events, such as the mastery and conversion of sustainable food agriculture land.

\section{Discussion}

\section{The Legal Basis of the Authority of the District/Manucipal Government in Regulating} Sustainable Food Agriculture

The government, both the provincial and district/manucipal governments, has a great duty, that is to say they carry out government activities, development and service to the community [13, 14]. The execution of these duties aimes at achieving national goals as mandated in the opening of Indonesian 1945 Constitution to improve the standard of living and welfare of the entire community. Based on this condition, the authority of the government to control the land is stipulated in the provisions in paragraph (1) of Article 2 Indonesian Basic Agrarian Law (UUPA). Based on this article, the authority can be authorized to the regional governments. The Regional government, in this case including the provincial government of Bali, is governments in the autonomous regions at the provincial level as stipulated in Act of Regional Government in the number of No. 23 of 2014. Thus, the provincial government is called an autonomous region. Land cultivation, especially agricultural land is included in land affairs which is part of mandatory government affairs that are not related to basic services, as referred to in Article 11 paragraph (2), which is also set forth in Article 12 paragraph (2) letter d of Law number 232014 concerning Regional Government.

Regarding the establishment of legislation, the authority to form it is in the hands of the House of Representatives which together with the president discuss and approve each draft law. Then the president ratifies the draft law that has received mutual agreement to become a law. The issuance of laws is essentially a joint power between the House of Representatives and the President (sharing power). Meanwhile, the authority to form legislation that is under the law is the authority of the president, regional head or the head of a ministry/institution in accordance with the duties and functions of its authorities specified in the law.

The authority of the district/manucipal government in making regional regulations concerning the Protection of Sustainable Food Agriculture (hereinafter referred to as PLP2B) 
refers to Act of sustainable protection of agriculture land of 2009, particularly that of paragraph 2 of Article 12. In the Act it is stated, "The planning for provincial sustainable food agriculture is a reference for planning sustainable food agriculture of the district/manucipality." In theory, the legal basis for district/manucipal governments in issuing regional regulations on $P L P 2 B$ is provincial regulations. But in fact the district government, in this case Jembrana District, stipulates regional regulations regarding $P L P 2 B$ by not referring to provincial regulations, as stipulated in Act of Establishment of Legislation in 2011, in paragraph 1 of Article 7, that the legal norms must be hierarchical.

In Article 12 paragraph (1) of $U U P L P 2 B$, it is said that there is a vagueness of norms because the use of the word "and" in the article which causes the potential to cause norm conflicts and not in accordance with hierarchical theory. The words "and" in the sentence can be interpreted as parallels between provinces and district/city, and thus it is contrary to hierarchical theory and contradicts Article 12 paragraph 2 of UUPLP2B.

Juridical Consequences of the Enactment of District/Manucipal Regulation Regarding Sustainable Food Agriculture Land Protection If It is Not Based on Provincial Regulation

Adherence to regional regulations in higher legislation has indeed been a concern for a number of groups of people. In 2016, the Ministry of Home Affairs announced that there were 3,143 regional regulations that had been canceled. In detail, out of 3,143 of the revoked or revised regional regulations, there are 1,765 regional regulations or district/manucipal head regulations which are revoked or revised by the interior minister. Then, 111 regulations or decisions of the interior minister are revoked or revised, and 1,267 regional regulations or district/manucipal head regulations are revoked or revised by the governor [15].

District/manucipal regulations are legislation established by the Regional People's Legislative Assembly (hereinafter referred to as the DPRD) district/mnucipal with the agreement of the regent/mayor. Meanwhile, provincial regulations are legislation established by the Provincial DPRD with the Governor's agreement.

Provisions regarding regional regulations, what prohibited from contradicting higher regulations are also clearly regulated in Number 23 of Article 250 in 2014 of the regulation. The Article reads, "Regional Regulations and Regional Head Regulations as referred to paragraph (1) and (3) of Article 249, is prohibited to be contrary to the provisions of higher laws, public interests, and/or decency. If the laws and regulations under the Act are contrary to the Law or higher laws and regulations, the minister in this case the Minister of Home Affairs shall revoke the regional regulation.

Likewise with the regional regulations of Jembrana District Number 5 of 2015 concerning Sustainable Food Farmland Protection, to realize regulatory legal certainty as such, the arrangement is not clearly made with regard to the references used by the district/manucipal government to form a regional regulation, so that multiple interpretations occur. This is especially for compliance with Indonesian Act of Agriculture Land Protection Number 41 of 2009, particularly in Article 12 paragraph (1) and (2). In this regard, the Jembrana regional regulation Number 5 of 2015 on the Sustainable Protection of Food Agriculture Land can be null and void because it is not based on regional regulations on Sustainable Food Agriculture of the Province. What is more, the Number 12 of Article 7 of Indonesian Act of Establishment of Legislation in 2011 stipulates that the legislation shall be executed in phases. In other words, provincial regulations are higher than district/manucipal regulations. Similarly, Article 12 paragraph (2) determines that the province becomes a reference for districts/manucipalities in the hierarchy. Thus, the juridical consequence of Jembrana Regional regulation is that it contradicts the Number 12 of Article 7 of Indonesian 
Establishment of Legislation in 2011 and Article 12 paragraph (2) UUPLP2B. If this is allowed to happen, it is not impossible that in a certain period of time it will cause unrest in the wider community due to the lack of clarity regarding the status of the regional regulation; it is among a conditions of having legal force or never. This has the potential to create legal uncertainty for the community.

\section{Conclusion}

The basis of the authority of the district/manucipality government in controlling the conversion of agriculture is the Number 41 of Article 12 of Indonesian Act of Agriculture Land Protection in 2009. Establishment of district/manucipality regulations, which in this case is the Jembrana District Regulation Number 5 Year 2015, directly refers to Law Number 41 of 2009 (Article 12 paragraph 1) because in the article it is stipulated that districts/manucipalities can refer to the constitution. Notwithstanding, in hierarchy article 12 paragraph 2 stipulates the district/manucipality refers to the provincial government.

The juridical consequence of the application of district/city regulations that do not refer to provincial regulations is that they are contrary to the Indonesian Act, which regulates the protection of agricultural land and the regulation is applicable.

At the end of the analysis in this study, there are several recommendations to be provided. The basis of the authority of the district/manucipality government in regulating sustainable food agricultural land contains the obscurity of legal norms, and therefore, it is recommended that the joint president of the DPR abolish Article 12 Paragraph 1 of Law Number 41 of 2009 because it contradicts Article 7 of Law Number 12 of 2011. Furthermore, in conjunction with the juridical consequences of the enactment of district/manucipality regulations that do not refer to provincial regulations, district/manucipality governments are expected not to take advantage of the provisions of the Act in making regional regulations, but referring to Article 12 (2) Law Number 41 of 2009.

\section{Acknowledgments}

The authors express the greatest gratitude to the organizing committee of the International Conference on Social Sciences (ICOSS) of Universitas Warmadewa for the great contribution that has been granted to the launching of this scientific script at EAI Publisher. Hopefully the ideas found in the paper can be additional to the theoretical and practical konwledge for many parties.

\section{References}

[1] A. Komarulzaman and A. S. Alisjahbana, "Testing the Natural Resource Curse Hypothesis in Indonesia: Evidence at the Regional Level," Work. Pap. Econ. Dev. Stud., no. 200602, 2006.

[2] R. Garnaut, "Indonesia'S Resources Boom in International Perspective: Policy Dilemmas and Options for Continued Strong Growth," Bull. Indones. Econ. Stud., vol. 51, no. 2, pp. 189-212, 2015.

[3] Z. Korani, "Application of teaching methods, promoting integrated pest management on the farm school in order to achieve sustainable agriculture," Procedia - Soc. Behav. Sci., vol. 47, pp. 2187-2191, 2012.

[4] A. Wasilewski, "Land Conversion for Suburban Housing: A Study of Urbanization Around Warsaw and Olsztyn , Poland," vol. 34, no. 2, pp. 291-303, 2004.

[5] S. Tan, "Impacts of Cultivated Land Conversion on Environmental Sustainability and 
Grain Self-sufficiency in China," vol. 16, no. 3, pp. 75-92, 2008.

[6] A. E. Gaughan, M. W. Binford, and J. Southworth, "Tourism, forest conversion , and land transformations in the Angkor basin , Cambodia," Appl. Geogr., vol. 29, no. 2, pp. 212-223, 2009.

[7] J. Qun, D. Xiangzheng, Z. Jinyan, and H. E. Shujin, "Estimation of Land Production and Its Response to Cultivated Land Conversion in North China Plain," vol. 21, no. 2010, pp. 685-694, 2011.

[8] A. S. H. A. Sasono, Ekonomi Politik Penguasaan Tanah. Jakarta: Pustaka Sinar Harapan, 1995.

[9] M. Adachi, "Agricultural and Tax Conversion in Japan," RURDS, vol. II, no. 2, 1999.

[10] H. Azadi, P. Ho, and L. Hasfiati, "AGRICULTURAL LAND CONVERSION DRIVERS : A COMPARISON BETWEEN LESS DEVELOPED , DEVELOPING AND DEVELOPED COUNTRIES," L. Degrad. Dev., vol. 604, no. September 2010, pp. 596-604, 2011.

[11] P. M. Marzuki, "Penelitian Hukum," Yuridikal, vol. 16, no. 1, pp. 89-111, 2001.

[12] S. Sukanto and S. Mamudji, Penelitian Hukum Normatif Suatu Tinjauan Singkat. Jakarta: Penerbit Raja Grafindo Persada, 2007.

[13] C. Mcmahon, E. M. Hartman, T. P. Review, and N. Apr, "Philosophical Review Authority and Democracy : A General Theory of Government and Management . by," vol. 105, no. 2, pp. 272-274, 2012.

[14] T. Lodge, "Provincial government and state authority in South Africa," J. South. Afr. Stud., vol. 31, no. 4, pp. 737-753, 2005.

[15] Kementerian Dalam Negeri Republik Indonesia, URL: http://www.kemendagri.go.id/media/filemanager/2016/06/21/b/a/batal_perda_21_juni_ 2016.pdf, Accessed on Pebruary 24 2017. . 